\title{
Vse slovenske G(e)rlice
}

\section{All "Slovene Turtledove" (Slovenske Gerlice)}

Ključne besede: Slovenska gerlica, Gerlica, Grlica

POVZETEK

Predmet obravnave so štiri glasbene zbirke s podobnimi naslovi: Slovenska gerlica, (Fleišmanova) Gerlica, (Kumarjeva) Grlica in revija Grlica. Naslov hoče objeti vse štiri zbirke, zato je nekoliko zapleten. - Slovenske gerlice je izšlo sedem zvezkov (1848, 1848, 1850, 1852, 1859, 1859, 1862). Tretji zvezek je uredil Gregor Rihar, morda tudi ostalih prvih šest. Peti in šesti zvezek sta celota $\mathrm{s}$ skupnim naslovom: Venec slovenskib pesem $\mathrm{dr}$. Fr. Prešern-a. Napevi od Kamillo Mašek-a. Sedmi zvezek je uredil Jurij Fleišman. - Potem ko je izdal 7., zadnji zvezek Slovenske gerlice, je Jurij Fleišman leta 1864 izdal drugo zbirko $\mathrm{v}$ treh zvezkih $\mathrm{z}$ naslovom Gerlica, v kateri je naredil izbor napevov iz prvotne zbirke. Zdi se, da Fleišman ni imel namena izdati celotne pesmarice, saj je pobral uspešnice iz Slovenske gerlice in jih izdal kot Gerlica. Poleg tega so v tretjem zvezku pesmi iz 1. in 2. zvezka. - Proti koncu leta 1933 je Srečko Kumar $v$ Zagrebu začel izdajati Grlico $s$ podnaslovom Revijalna zbirka omladinske muzike,
Keywords: Slovene Turtledove, Turtledove, Turtledove Review

\section{SUMMARY}

The subject under discussion deals with four music collections with similar titles: Slovene Turtledove (Slovenska gerlica), (Fleišman's) Turtledove (Gerlica), (Kumar's) Turtledove (Grlica) and the Turtledove Review (Grlica). Hence the rather complicated heading of the article. - The Slovene Turtledove was published in seven volumes $(1848,1848,1850,1852$, $1859,1859,1862$ ). The third was edited by Gregor Rihar, and so were presumably the other six volumes. The fifth and the sixth represent a whole under the title: $A$ Wreatb of Slovene Poems by Dr. Fr. Prešeren. Tunes by Kamilo Mašek (Venec slovenskih pesem dr. Fr. Prešern-á. Napevi od Kamillo Mašek-a). The seventh volume was edited by Jurij Fleišman. After having issued the seventh, i.e. last volume of the Slovene Turtledove, in 1864 Jurij Fleišman published a second edition in three volumes under the title Turtledove, in which he made a selection of melodies from the former collection. Fleišman does not seem to have intended to publish the entire songbook, choosing only the "hits" from the Slovene 
ki jo je sam urejal in izclajal. - Leta 1953 je začela izhajati revija Grlica s podnaslovom Revija za mladinsko zborovsko glasbo, ki jo je izdajal Aktiv ljubljanskih srednješolskih profesorjev glasbe, založila pa Mladinska knjiga. Z 9. letnikom se je Grlica iz Revije za mladinsko zborovsko glasbo prelevila $\mathrm{v}$ Revijo za glasbeno vzgojo, hkrati je odgovorno uredništvo prevzel pavle Kalan. Sprememba je bila napovedana v uvodniku Grlica pred novimi nalogami, ki sta ga podpisala uredništvo in uprava. Sprememba ni bila toliko $v$ glasbenih prilogah kot v knjižnem delu. Grlica je leta 1988 po 35 letih od ustanovitve, vendar v 28. letniku sklenila svoje izhajanje.
Turtledove, and issuing them as Turtledove. Apart from that, the third volume also contains songs from the first and second volume. - In Zagreb, towards the end of 1933, Srečko Kumar began editing and publishing a Periodical collection of youtb music (Revijalna zbirka omladinske muzike), titled Turtledove. - In 1953, another Turtledove began to appear, this time with the subtitle Magazine for choral youth music, issued by the Work team of the l.jubljiana secondary school music teachers, and published by Mladinska knjiga. In its ninth year of publication it was converted into a periodical for music education, with Pavle Kalan as editor. The changes were explained in an editorial under the heading Turtledove facing new tasks, and signed by the editorial and administrative boards. The musical supplements hardly altered in contrast to the changes in the textual sections. Nevertheless, in 1988, after 35 years since its founding, Turtledove, having reached its 28 th volume, ceased to be published for good.

Predmet obravnave v tem članku so štiri glasbene zbirke s podobnimi naslovi: Slovenska gerlica, ${ }^{1}$ (Fleišmanova) Gerlica, (Kumarjeva) Grlica ${ }^{2}$ in revija Grlica. ${ }^{3}$ Naslov hoče objeti vse štiri zbirke, zato je nekoliko zapleten.

Ko je Anton Slomšek "na svetlo dal" Drobtince za novo leto 1846 , je vsebino razdelil takole:
A. Stare resnice $v$ novi obleki.
B. Prigodbe vesele in žalostne.
C. Razgled za stare ino mlade.
D. Prilike ino basni.
E. Ogledalo za šolo.
F. Slovenska gerlica.

Na naslednji strani razdelka je dvostih, ki bo z večjimi ali manjšimi spremembami ostal vodilo naslednjim izdajam:

"Slovenska gerlica $v$ domačim logi rahlo poje,

Povabi spevati vse brate ino sestre svoje."

Razdelek Slovenska gerlica ima naslednje skupine:

I. Pesme ljubeznive matere.

II. Pesme za dobro voljo.

III. Pesme za kratek čas.

IV. Pesme za pobožnost. Zadnja v tej skupini je Slomškova $V$ nebesib sem doma.

Slomšek je uredil le prva dva letnika Drobtinc, ker mu škofovska obremenitev ni dopuščala, da bi zbornik še naprej urejal. Nasledil ga je celjski opat Matija Vodušek. Drobtinc je izšlo 20

1 Prim. J. Snoj, Slotenska gerfica, v: ES.

2 Ceprav je Srecko Kumar jzdajal svojo Grlico v Zagrebu, jo smemo uvrstiti med slovenske izdaje, saj so pri njej sodelovali številni slovenski skladatelji in glasbeni pjsci. $V$ Grlici so namreč izlajalli clanki in skladbe v slovenščini in hrvaščni.

I'rim. J. Snoj, Grica, v: ES. 
letnikov. Ker so bili nekateri letniki dvojni, nosi 20. letnik letnico 1869. Od 1846 so izhajale v Gradcu, od leta 1863 pa v Mariboru z naslovom Slomskove Drobtinice. Vseh prvih 20 letnikov ima razdelek Slovenska gerlica. Leta 1887 jih je v Ljubljani obnovil Frančišek Lampe z naslovom Drobtinice in so izhajale do leta 1901, vendar brez Slovenske gerlice. ${ }^{4}$

\section{Slovenska gerlica}

Mesec dni po marčni revoluciji, aprila 1848 , je bilo v Ljubljani ustanovljeno Slovensko društvo, ki je zlasti pod Bleiweisovim vodstvom poudarjalo uveljavljanje slovenščine v javnosti. To so skušali doseči z vrsto kulturnih prireditev (béseda), dramskimi predstavami, zbiranjem gradiva za slovar slovenskega jezika, organiziranjem skupine, ki je pripravljala slovenski prevod zakonov s področja civilnega in kazenskega prava, zavzemali so se za ustanovitev univerze $\mathrm{v}$ Ljubljani. Po zaslugi društva so poslovenili ulična imena v Ljubljani. ${ }^{5}$

Prva beseda je bila že 30. maja 1848. Poročilo v Novicab mdr. pravi: "Vsi spevi so obilno zbranim poslušavcam takó močno dopadli, de niso bili zadovoljni, jih le enkrat slišati; iz vsih straní je donélo 'še enkrat, še enkrat.' Resnica je pa tudi, da zala pevka, vsi pevci in govorniki so se tako slavno obnašali, de današnja beseda je bila gotovo nar prijetniši vsih letašnjih Ljubljanskih koncertov." Poročilo pa sklene: "Ne moremo tega popisa dokončati, de bi se ne zahvalili gosp. Bučarju, ki si je za napravo perve slovenske besede toliko truda prizadjal; pohvaliti moramo pa tudi gosp. Mašeka, učenika Ljubljanske muzikalne šole, ki je le za klavir napravljene rečíla pa $v$ celo muziko prestavil in pa gosp. Fleišmana, ki s pravim veseljem in hvale vredno umetnostjo napeve slovenskih pesem zlaga. Tudi orkester se je dobro deržal. . ${ }^{6}$

Druga beseda je bila po treh tednih, 19. junija 1848. Med drugim Bleiweisove Novice poročajo: „Po tem je nastopil pevec Prešernove mične pesmi 'Pod oknam', ktero je gosp. Fleišman v kej prijetni napev zložil, ktero nam je gosp. Pevec tudi prav lepo zapel in poslušavcam globoko $\mathrm{v}$ srce segel [...] Bleško jezero, pesem zloženo od gosp. K. Hueberja in v muziko postavljeno od mladiga gosp. Mašeka, so gospodične v zboru prav prijetno dvakrat pele. ${ }^{7}$

Novice iz 2. avgusta 1848 prinašajo Razglas pomenkov in opravil slovenskiga družtva $v$ Ljubljani v odbornib sejah. Številka 8 se glasi: "Se je sklenilo na svitlo dati vse doslej v gledišu pete slovenske pesmi, in se je izročila ta naloga posebnimu odboru. " 8 Žal ne pove, kdo so odborniki bili. Glede na prejšnje poročilo bi lahko sklepali, da sta bila zanesljivo Mašek in Fleišman, morda pa tudi Bučar kot nujno tretji. Tako sta nastala oba prva zvezka Slovenske gerlice. Bila sta prav kmalu tiskana, kajti Novice z dne 4. oktobra 1848 prinašajo pod naslovom Slovenske pesmi naslednje sporočilo: "Iz zbirke slovenskih pesem, pod naslovam Slovenska gerlica, izdavana od slovenskiga družtva v Ljubljani, sta ravno perva dva že davnej pričakovana zvezka na svitlo prišla, in se dobista, zvezek po $15 \mathrm{kr}$, v pisarnici slovenskiga družtva in pri gosp. J. Blazniku na prodaj. Pervi zvezek obseže 11 , drugi $10 \mathrm{v}$ Ljubljanskim gledišu petih pesem; besede in note za petje in glasovir (klavir) so v prav ličnim tisku; zato bosta ta dva zvezka vsim prijatlam in prijatlicam domačiga petja gotovo zlo dopadla. ${ }^{9}$ Na občnem zboru 22. novembra 1848 pa je bilo poveclano, da "prodajajo se zlo"."

\footnotetext{
Prim. J. Sifrer, Droblinice, v: ES. Pravzaprav ni jasnu, zakaj se pesmarica inenuje po grlici, ki ni ptica pevka, saj ne poje, ampak gruli. Prim. S. Granda, Slovensko drištuo, v: ES.

Dr. B[leiwejs], Prua beseda Ljubljanskiga stotchskiga zbora v ljubljanskim gledišu, 30. dan veliciga tratma, v: N 6 (1848), 96; prireditev jo bila 30. maja in ne 30. aprilat, kot nekateri pišejo.

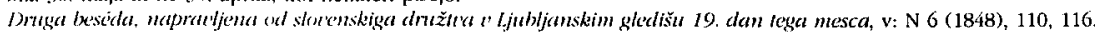

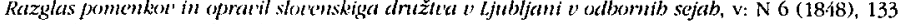

Slouenske pesmi, v: N 6 (1848), 170.

10 Velki zbor slovenskiga dmižtua v Ljubljani 22. listopacla, v: N 6 (1848), 218: "Slov. pesem smo nabrali dva zvezka in ju pod naslovam: Slov gerilica na svitlo dali na potroške druz̆rva. Prodajajo se \%lo,.
} 
Slovenske gerlice je izšlo sedem zvezkov. Iz naslednjega seznama razberemo naslov pesmi. zasedbo, avtorja skladbe in avtorja besedila.

[1.] Slovenska gerlica. Venec slovenskib pesem na svitlo dan od Slovenskiga družtva $v$ Ljubljani. Prvi zvezek. [Ljubljana 1848]

Zvezek ima naslednje skladbe:

Skladatelj:

Napev stari

1. Slovencov nár
2. Slovenski duh

3. Popotnik

4. Veselja dom

5. Dolenska

6. Pôd oknam

7. Moje jutro

8. Moje drago

9. Dolenska zdravica

10. Zadovoljni Krajnc

11. Zvonikarjeva
napev s kl.
Po národno slovanski pesmi
napev s $\mathrm{kl}$.
napev $\mathrm{s} \mathrm{kl}$.
napev $\mathrm{s} \mathrm{kl}$.
A. M. Slomšek
B. Potočnik
napev $\mathrm{s} \mathrm{kl}$.
J. Fleišman
J. Padovec
J. Padovec
napev $\mathrm{s} \mathrm{kl}$.
napev $\mathrm{s} \mathrm{kl}$.
napev $\mathrm{s} \mathrm{kl}$.
Iz pesem krajnskiga naroda

napev $s \mathrm{kl}$.
Pesnik:

B. Potočnik

J. Strela

A. M. Slomšek

B. Potočnik

F. Prešeren

L. Vukotinovič

L. Vukotinovič

V. Vodnik

B. Potočnik

[2.] Slovenska gerlica. Venec slovenskib pesem na svitlo dan od Slovenskiga družtva $v$ Ljubljani. Drugi zvezek. [Ljubljana 1848]

1. Naprej

2. Slovenca dom

3. Mornar

4. Slovenska deklica

5. Planinar

6. Tri pesmice $v$ eni

7. Bleško jezero

8. Gorenska zdravica

9. Pesem slovenskih [...]

10. Moj spominik

$\begin{array}{ll}\text { napev s kl. } & \text { Napev ilirski } \\ \text { napev s kl. } & \text { Napev slovanski } \\ \text { napev s kl. } & \text { J. Fleišman } \\ \text { napev s kl. } & \text { Napev ilirski } \\ \text { napev s kl. } & \text { B. Potočnik } \\ \text { napev s kl. } & \text { Napev ilirski } \\ \text { napev s kl. } & \text { K. Mašek } \\ \text { napev s kl. } & \text { Gorenska pesem } \\ \text { napev s kl. } & \text { J. Fleišman } \\ \text { napev s kl. } & \text { Napev star kranjski }\end{array}$

Jeriša (pr.)

A. Pirnat

F. Prešeren

Jeriša (pr.)

B. Potočnik

L. Vukotinovič

K. Huber

-

F. Malavašič

V. Vodnik

1. in 2. zvezek sta leta 1852 doživela drugi natis, in sicer tako zvesto, da je pri cesarski himni še vedno omenjen cesar Ferdinand, čeprav je že 2. decembra 1848 prestol zasedel cesar Franc Jožef I. ${ }^{11}$

[3.] Slovenska gerlica. Venec slovenskib pesem na svillo dan od Slovenskiga družtva $v$ Ljubljani. Tretji zvezek. [Ljubljana 1850]

1. Planinar

2. Dolenska

3. Zvonikarjeva

4. Svarjenje

5. Stari Krajnc

6. Vse mine napev $\mathrm{s} \mathrm{kl}$.

a) razstavno $\mathrm{s} \mathrm{kl}$.

b) sostavno

[sostavno] s kl.

[razstavno]

napev s $\mathrm{kl}$.

a) razstavno

b) sostavno
B. Potočnik

B. Potočnik

B. Potočnik

B. Potočnik

Krajnska národna pesem

J. Fleišman

Slovenska národna pesem

Slovenska narodna pesem
B. Potočnik

B. Potočnik

B. Potočnik

B. Potočnik

Poženčăn

\footnotetext{
11 Prim. B. Wacha. Mabshurzami. L.jubljana 199d, 388.
} 
7. Strunam

sostavno $\mathrm{s} \mathrm{kl}$.

8. Spomin Val, Vodnika

9. Sarafan

10. Slavska reč a) razstavno $\mathrm{skl}$.

b) sostavno napev $\mathrm{s} \mathrm{kl}$. [sostavno]
F. Prešeren

F. Prešeren

J. Fleišman

J. Fleišman

Pisma [...] od Dragića Rusana

3. zvezek je izšel šele leta 1850, saj v Novicah beremo: "3. zvezek Slovenske gerlice (slovenskih pesem $z$ napevi) od slovenskiga družtva $v$ Ljubljani na svitlo dajane, je prišel ravno zdej od slavniga gospoda Riharja v red djan na svitlo. Gosp. udje v Ljubljani so naprošeni, ga v pisarnici pri gosp. Brusu brez plačila sprejeti; gosp. udam po deželi se bo po pošti poslal. Kdor ta zvezek kupiti želi, ga dobi pri gosp. Blazniku za 15 krajc."12

[4.] Slovenska gerlica. Venec slovenskih pesem na svitlo dan od Slovenskiga družtva $v$ Ljubljani. Četerti zvezek. Natis iz kamnotiskanice Jožefa Blaznika 1852.
[1.] Zdravica
napev + 4-glas.
B. Ipavic
G. Križan
[2.] Slovo od lastovke
Stara kranjska
13.] Milica
napev $\mathrm{s} \mathrm{kl}$.
[4.] Vsakimu svoje!
Napev moravski
V. Orožen
napev $\mathrm{s} \mathrm{kl}$.
V. Lisinski
15.] Veseli godec
G. Rihar
napev $\mathrm{s} \mathrm{kl}$.
Napev češki [...]
[6.] Vojaška
napev $s \mathrm{kl}$.
napev s $\mathrm{kl}$.
[7.] Prevzetna
Gorenska pesmica
[8.] Prediška
napev $s \mathrm{kl}$.
Fr. Markiseti
Fr. Cegnar
Fr. Cegnar
J. Žemlja
[9.] Zdravica
napev $\mathrm{s} \mathrm{kl}$.
B. Potočnik
Fr. Cegnar
napev $\mathrm{s} \mathrm{kl}$.
G. Rihar
Poženčan
B. Potočnik
J. Uršič

Tudi za 4. zvezek vemo, kdaj je izšel. Poleg tega da je letnica pri tiskarju, leta 1852 v Novicab piše: "Četerti zvezek Gerlice, izdajane po slovenskim družtvu v Ljubljani, je prišel na svetlo. Zapopade v ličnim natisu in zvezku deset pesm z napevi (vižami) za klavir, ktere bojo gotovo pevcam in pevkam prav všeč. Veličina 4 . zvezka je kakor je bila pervih dveh zvezkov. Dobi se v gosp. Blaznikovi tiskarnici v Ljubljani za 15 krajc." ${ }^{13} \mathrm{Za}$ naklado ne vemo, vemo pa, da je leta 1853 Blaznik imel še vse štiri zvezke na zalogi: "Slovenska gerlica, to je, zbirka naj lepših slovenskih pesem, I., II., III. in IV. zvezik, se dobiva v založbi J. Blaznika v Ljubljani na bregu Nr. 190 po 15 krajc. zvezik." ${ }^{1 / 4}$

Iz poročila zvemo, da je bil 3. zvezek "od slavniga gospoda Riharja v red djan". Ne vemo pa, kdo je uredil 1., 2. in 4. zvezek. Rihar je bil edini človek, ki je v Ljubljani imel izkušnje z urejanjem pesmaric. Leta 1844 in 1845 je izdal oba zvezka Viž za svete pesmi, ki so bile po obsegu nekaj izjemnega že same na sebi, kaj šele v tedanjih okoliščinah. Pa tudi kot tiskarski podvig so Viže velikanski uspeh. Zato ga je lahko Slovensko društvo naprosilo, naj uredi prve zvezke Slovenske gerlice. Iz tega lahko sklepamo, da je možno, morda celo verjetno, da je Gregor Rihar uredil prve štiri zvezke zbirke. ${ }^{15}$ Tega mnenja je tudi Pavel Kozina. ${ }^{16}$

Gregor Rihar je šele v 4. zvezku objavil dve lastni skladbi: Veseli godec in Življenje, ki ga je Gregor Rihar ml. vključil med Národne napeve, ki jih je po skladateljevi smrti založila Jera Rihar. ${ }^{17}$ Zanimiv primer pa predstavlja skladba Strunam na Prešernovo besedilo, ki je izšla

12 3. zeezek slowenske serice, v: N $8(1850), 124$

$13 \mathrm{~N} 10$ (1852), Oglasnik št. 33.

14 N 11 (1853), Oglasnik št. 21 (prva dva zvezka seveda v ponatisu).

15 Prim. E. Škulj, Gregor Rihar (1706-1863), Ljubljana 2003, 71-76.

16 Prim. P. Kozina, Gregor Ribarjeta Strunam, v; Z 2 (1926), 46-48.

17 V 7. zvezku je izšla še Riharjeva Sacica, ki je iłšla leta $1854 \mathrm{v}$ Vencu ćucteroglasnih pesem, ki ga je izdal sklactatelj sam. 
trikrat, in sicer prvič brez navedbe skladatelja v 3. zvezku Slovenske gerlice, ki ga je zanesljivo uredil Gregor Rihar, drugič v 5. zvezku med skladbami Kamila Maška, in sicer na prvem mestu, tretjič pa v 3. zvezku Gerlice, kjer je urednik Jurij Fleišman kot skladatelja navedel: "G. Richar." V to vprašanje se je leta 1926 poglobil Pavel Kozina in izsledke objavil v Zborih. ${ }^{18}$ Žal, avtor ni ustrezno ugotovil izhajanja Slovenske gerlice, saj pri obeh izdajah poenostavlja naslov zbirke in vse zvezke imenuje kar Gerlica.

[5.] Slovenska gerlica. Venec slovenskib pesem dr. Fr. Prešem-a. Napevi od Kamillo Mašek-a. $\quad$. Peti zuezek. V Ljubljani 1859.

1. Strúnam

2. Deklétam

3. a) Pod ôknam

b) Pod ôknam

4. Prôšnja

5. Kam?

6. Ukázi

7. $\mathrm{K}$ slovésu

8. Sila spominja 4-gl. s kl.

naper s $\mathrm{kl}$.

naper s $\mathrm{kl}$.

napev s kl.

napev $\mathrm{s} \mathrm{kl}$.

napev $\mathrm{s} \mathrm{kl}$.

napev $s \mathrm{kl}$.

napev s $\mathrm{kl}$.

naper s $\mathrm{kl}$.
Kamillo Mašek
Kamillo Mašek
Kamillo Mašek
Kamillo Mašek
Kamillo Mašek
Kamillo Mašek
Kamillo Mašek
Kamillo Mašek
Kamillo Mašek

France Prešern

France Prešern

France Prešern

France Prešern

France Prešern

France Prešem

France Prešern

France Prešern

France Prešern

[6.] Slovenska gerlica. Venec slovenskib pesem dr. Fr. Prešern-a. Napevi od Kamillo Mašek-a. Šesti zvezek. VLjubljani 1859.

9. Zgubljêna vera

10. Mornar

11. a) Soldáška

b) Soldáška

12. V spominj Valentina [...]

13. V spominj Andréja [...]

14. Od želézne céste

15. Zapušêna

16. Nezakónska máti napev $\mathrm{s} \mathrm{kl}$.

napev s $\mathrm{kl}$.

napev $\mathrm{s} \mathrm{kl}$.

4-gl. moški zhor

naper s kl.

napev in 4-gl.

dvospev

napev s $\mathrm{kl}$.

napev s kl.
Kamillo Mašek

Kamillo Mašek

Kamillo Mašek

Kamilo Mašek

Kamillo Mašek

Kamillo Mašek

Kamillo Mašek

Kamillo Mašek

Kamillo Mašek
France Prešern

France Prešern

France Prešern

France Prešern

France Prešern

France Prešern

France Prešern

France Prešern

France Prešern

5. in 6. zvezek sta zasnovana kot celota, zato se oštevilčenje 5 . nadaljuje v 6. zvezku. Razen prve so vse skladbe tukaj prvič objavljene. Vprašanje pa je, kdaj so te skladbe nastale. Iz skladb samih bi težko prepoznali kakšno skladateljevo zorenje, zato je težko določati vrstni red nastajanja. Sicer pa, ker gredo skladbe po vrsti glede na vrstni red v Prešernovih Poezijab, bi lahko mislili, da so tudi v tem vrstnem redu nastale. Drugo vprašanje zadeva glasbeno obliko. Ali so to samospevi? Če hočemo odgovoriti na to vprašanje, se moramo vrniti v leto 1848 in imeti pred očmi vso zbirko Slovenskih gerlic. Iz poročil o izvajanju v besedah in iz namena, ki ga je imela Slovenska gerlica, bi težko sklepali, da so bile izvedene skladbe pravi samospevi. Res je, da je "zala pevka" sama zapela ob spremljavi klavirja, drugo skladbo pa so "gospodične $\checkmark$ zboru " zapele. Verjetno gre bolj za enoglasne zbore s klavirjem, ki ga lahko zapoje en sam pevec, kot pa za prave samospeve. Tudi če pogledamo oba prva zvezka Slovenske gerlice, so vse skladbe napev s klavirjem ali morda celo klavirske skladbe s podloženim besedilom.

5. in 6. zvezek Slovenske gerlice nosita sicer letnico 1859, vendar tega leta nista izšla, saj v Novicab na začetku leta 1860 beremo: "Zornica nam je bila obljubljena, ravno tako 5. zvezek 
Slovenske gerlice, pa ne una ne ta se ni zgodila." ${ }^{19}$ Pač pa sta izšla leta 1860. Spet v Novicab beremo: "Slovenska Gerlica; 5. zvezek. Pesmi Prešernove, napevi Mašekovi. Pesnik in skladatelj počivata $v$ hladnem grobu, njune kosti trohnijo pod grudo, oba spita večno spanje $v$ černi zemlji do sodnega dne; ali njuni umotvori živijo med nami, razveseljujejo nam serca, budijo nas $k$ clelavnosti in vabijo $k$ posnemanju. Težko smo pričakovali Gerlice, prišla je in prinesla nam zraven medu dosti pelina, opomnivša nas: ni ga več, ki me je poslal k vam! Slovenska Gerlica; 6. zvezek. (Kakor pri 5. zvezku)., ${ }^{20}$

Kdo je uredil 5. in 6. zvezek Slovenske gerlice? Kamilo Mašek je umrl 29. junija $1859 \mathrm{v}$ Stainzu na Štajerskem, kamor je odšel na zdravljenje že 19. maja. ${ }^{21}$ Potemtakem svoje zbirke sploh ni viclel tiskane. Še holj pomembno pa je, da ni opravil korektur, ker je tiskarskih napak kar precej, in to očitnih. ${ }^{22}$

[7.] Slovenska gerlica. Venec slovenskib pesem na suitlo dan od Slovenskiga družtva $v$ Ljubljani. Sedmi zvezek. Natis iz kamnotiskarnice Jožefa Blaznika. [1862]
[1.] Burdnica
[2.] Savica
[3.] Samče
[4.] Prostost
[5.] Na razhodu
[6.] September
[7.] Studenček
[8.] Ločenje
[9.] Delapust
[10.] Sanjač
[11.] Gorska

moški zb.

moški zb.

mešani $z b$.

2-spev s kl.

2-spev s kl.

napev $\mathrm{s} \mathrm{kl}$.

moški zb.

2-spev s kl.

napev $\mathrm{s} \mathrm{kl}$.

2-spev s kl.

2-spev s kl.
Dr L. Toman-a / Nap. G. Riharja

Dr L. Toman-a / Nap. J. Fleišman-a

Bes. Dr L. Toman-a / Napev J. Goršič-a

Besede Vilher-ja / Nap. J. Fleišman-a

Besede Obalo / Nap. J. Fleišman-a

Posl. Ant. Leban

Besede Praprotnik-a / Nap. J.Fleišman-a

J. Hašnik-a

Narodna

Iz kratke notice v Novicah zvemo: "Slovenska gerlica, 7. zvezek, sostavil Juri Fleišman. ${ }^{23}$

\section{Fleišmanova Gerlica}

Potem ko je izdal 7., zadnji zvezek Slovenske gerlice, je Jurij Fleišman ${ }^{24}$ leta 1864 izdal drugo zbirko v treh zvezkih z naslovom Gerlica, v kateri je naredil izbor napevov iz prvotne zbirke. V Novicah namreč beremo: "Slovenska Gerlica; pomnožena nova izdaja. Trije zvezki; vredil Juri Fleišman. Gerlice imamo do zdaj sedem zvezkov.“ ${ }^{25}$

Zvezki so imeli naslednjo vsebino:

19 A. K. Cestnikov, Slotensko sloustio v letu 1859, v: N 18 (1860), 5.

20 A. K. Cestnikov, Slovensko slovstwo v letu 1860, v: N 19 (1861), 22.

21 Prim. J. Mantuani, Mašek Kamilo, v: SBL II, Ljubljana 1933-1952, 69.

22 Prim. E. Škulj, Kamilo Mašck in France Prešeren, v: Maškov zbornik, Ljubljana 2002, 123-134.

23 A. K. Cestnikov, Slotensko sloustuo v tetu 1862, v: N 21 (1863), 20.

2- Jurij Fleišman (Beričevo, 18. 4. 1818 - Ljubljana, 23. 5. 1874) je bil po poklicu učiteli, v glasbi pa samouk $z$ razmeroma preprosto kompozicijsko telıniko. Bil je ključná skladateljska osebnost $v$ dobi nacionalneggi navdušenja, ki ga je spodluudila marčna revolucija. Njegove skladbe so večinoma izšle v zbirkah Solarke pesmi (1860), Mične slovenske zdravice -IV(1860-1863), Slovanska beseda 1 III (1864), pá ludi v več zvezkih Slotenske gerlice (1848-1862). Kot zgodnji romantik se je opiral na klasicistične vzore. Zaradi prikupne melodike in ljudske

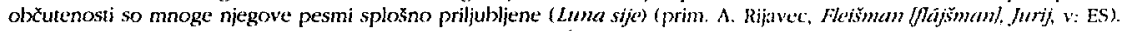

25 A. Kos, Pregled slovenskega slovstua v letu 1864, v: N 23 (1865), 12. 
[1.] Gerlica. Venec slovenskih pesem. Vredil J. Fleišman. I. zvezek. Nova izdaja. Cena 50 krc. Založil in natisnil jožef Blaznik v Ljubljani. [1864]

[1.] Cesarska pesem

[2.] Slovenski duh

[3.] Popotnik

[4.] Veselja dom

[5.] Dolenska

[6.] Pod ôknam

[7.] Moje jutro

[8.] Moje drago

19.] Dolenska zdravica

[10.] Zadovoljni Krajnc

[11.] Zvonikarjeva

[12.] Občutki

[13.] $\mathrm{Na}$ jezeru mešani zb.

mešani $z b$.

napev $\mathrm{s} \mathrm{kl}$.

napev $\mathrm{s} \mathrm{kl}$.

2-spev s kl.

moški zb.

napev s kl.

napev $\mathrm{s} \mathrm{kl}$.

2-spev s kl.

napev s $\mathrm{kl}$.

moški zb.

napev s $\mathrm{kl}$.
Národna pesem

Besede J. Strelove / Napev stari

Besede in napev A. M. Slomšeka

Besede in napev $B$. Potočnika

Besede Dor Prešernove / Napev J. Fleišmanov

Besede Ljud. Vukotinoviča / Napev J. Padovcov

Besede Ljud. Vukotinoviča / Napev J. Padovcov

Iz pesem krajnskiga naroda

Besede V. Vodnikove / Napev stari krajnski

Besede in napev B. Potočnika

Besede Dor L. Toman-a /

Napev Josipine Turnogradske Toman-ove

Besede in napev $M$. Vilharja

[2.] Gerlica. Venec slovenskih pesem. Vredil. Fleišman. II. zvezek. Nova izdaja. Cena 50 krc. Založil in natisnil Jožef Blaznik v Ljubljani. [1864]

[1.] Naprej

[2.] Slovenca dom

[3.] Mornár

[4.] Slovenska deklica

[5.] Planinar

[6.] Tri pesmi $v$ eni

[7.] Bleško jezero

[8.] Zdravica

[9.] Pesem stražnikov

[10.] Moj spominik

[11.] Ljubezin domovine

[12.] Lahko noč
napev s ki.
napev $\mathrm{s} \mathrm{kl}$.
napev $\mathrm{s} k \mathrm{k}$.
napev s kl.
napev s kl.
napev s kl.
napev $\mathrm{s} \mathrm{kl}$.
napev $\mathrm{s} \mathrm{kl}$.
napev s $\mathrm{kl}$.
napev s $\mathrm{kl}$.
napev $\mathrm{s} \mathrm{kl}$.
moški zb.

[3.] Gerlica. Venec slovenskib pesem. Vredil J. Fleišman. III. zvezek. Nova izdaja. Cena 50 krc. Založil in natisnil Jožef Blaznikv Ljubljani. [1864]

[1.] Planinar

[2.] Dolenska

[3.] Zvonikarjeva

[4.] Stvarjenje

[5.] Stari Krajnc

[6.] Vse mine

[7.] Strunam

[8.] Spomin Vodnika

[9.] Sarafan

[10.] Slovanska reč

[11.] Zvečirna napev $\mathrm{s} \mathrm{kl}$. mešani zb.

napev s $\mathrm{kl}$.

mešani zb.

napev $\mathrm{s} \mathrm{kl}$.

mešani zb.

moški zb.

mešani zb.

napev s kl.
Besede in napev B. Potočnika

Besede in napev Blaža Potočnika

Besede in napev B. Potočnika

Narodna pesem

Besede Poženčana / Napev J. Fleišman-a

Narodna pesem

Besede Dr Prešerna / Napev G. Richarja

Besede Dr Prešérna / Napev J. Fleišman-a

Slovanska n[arodna]

moški zb.

Slovanska narodna

moški zb.
J. Fleišman-a 
Zdi se, da Fleišman ni imel namena izdati celotne pesmarice, saj je pobral uspešnice iz Slovenske gerlice in jil izdal kot Gerlica. Poleg tega so v tretjem zvezku pesmi iz 1. in 2. zvezka. To bi nakazovalo na dejstvo, da vsi trije zvezki le niso izšli sočasno, čeprav vsi v teku leta 1864.

\section{Kumarjeva Grlica}

Proti koncu leta 1933 je Srečko Kumar ${ }^{26}$ v Zagrebu začel izclajati Grlico s podnaslovom Revijalna zbirka omladinske muzike, ki jo je sam urejal in izdajal. Proti koncu Uvodne besede opiše svoj načrt: "Sklenil sem zbrati snov, ki odgovarja v prvi vrsti umetniškim principom in jo porazdeliti tako, da jo izdam v desetih zaporednih mesečnih zvezkih. Vsak zvezek bo imel 24 tiskanih notnih strani in bo sestavljen tako, da ga mladinski zbori - katerim je namenjen - lahko uporabijo v celoti kot program enega šolskega koncerta. Ako se ena ali druga pesem izpusti, bo program še vedno dovolj obširen. V poznejših zvezkih podam navodila, kako se dajo programi kombinirati iz snovi različnih zvezkov. Vsak zvezek bo imel književno prilogo na ca. 8 straneh z estetskopedagoškimi članki, razpravami, vprašanji, biografijami, poročili. Ob koncu leta se bodo dali deseteri zvezki povezati v knjigo: priloge skupaj, note skupaj in tako bo zbirka podala verno sliko mladinske glasbene literature ene cele dobe. ${ }^{27}$

Iz kratkih notic na platnicah zvemo, da je prvi zvezek izšel decembra 1933 in da ndrugi zvezek izide ob božiču. Zvezki imajo naslednje oznake: I (1933-1934), II (1933-1934), III (1933-1934), IV (1933-1934), V (1933-1934), VI-VII (1934-1935), VIII-IX-X (1934-1935). Med pisci so: Adamič E., Druzovič H., Grbec I., Sancin M.; med skladatelji pa: Adamič E., Bravničar M., Grbec I., Kogoj M., Luzevič F., Osterc S. ${ }^{28}$ Na koncu desetega zvezka je Kumar v Listinici uredništva poročal: "S pričujočim desetim zvezkom je revijalna zbirka mladinskih zborov zaključena. S tem smo izpolnili našim naročnikom dano obvezo. Da se je mogel ta cilj doseči, gre $v$ prvi vrsti hvaležnost našim sotrudnikom za tako veliko število poslanih pesmi; nadalje dobri volji in potrpežljivosti naročnikov, vkljub zamudi nekaterih zvezkov; za nagrado za to smo književno prilogo povečali za nekoliko strani."

\section{Revija Grlica}

Leta 1953 je začela izhajati revija Grlica s podnaslovom Revija za mladinsko zborovsko glasbo, ki jo je izdajal Aktiv ljubljanskih srednješolskih profesorjev glasbe, založila pa Mladinska knjiga. Uredniški odbor so sestavljali Radovan Gobec (odgovorni urednik), Pavle Kalan, Janez Kuhar, Slavko Mihelčič in Ciril Pregelj. Uvodnik z naslovom Nă̌ delouni načrt se najprej navezuje na Kumarjevo Grlico: "Odkar je prenehala izhajati zadnja mladinska glasbena revija (Srečko Kumar: Grlica), bo kmalu minilo 20 let. V tem času se je spremenilo marsikaj. Hvaležni smo sicer uredniku Srečku Kumarju in njegovi edinstveni zbirki, ki je postavila [slovensko] mladinsko zborovsko glasbo na evropsko višino in skrbela mladinske zbore $s$ tolikšnim bogastvom, da ga ne bodo izčrpali še nekaj desetletij; vendar pa je treba vzeti v poštev dejstvo,

\footnotetext{
26 Srečko Kumar (Kojsko, 1. 4. 1888 - Pororož, 9. 2. 1954), glasbeni pedagog in zborovodja. Leta 1913 je diplomiral iz klavirja na konservatoriju Tartini $v$ Trstu in se izpopolnjeval $v$ Leipzigu. Obelajoco pianistično kariero je kmalu zamenjal s pedagoškim in narodnoobrambnim prosvetnim delom. V Trstu je ustanovil in vodil pevski zbor Učiteljske zveze Julijske krajine (1921-1926), v Ljubljani pa Učiteljski pevski zhor (1925-1934). Deloval je tudi v Zagrebu (1927-1936) kot profesor na GA in Glasbeni šoli Lisinski ter zborovodja pevskega z.lora Kolo. V Beogradu je bil (1936-1945) učitelj na raznil glasbenih šlah, po vojni pa na rodnem Gorišken (1945-1947) in Koprskem, kjer je postavil temelje glasbenega šolstva. Po vrsti zborovodskih in glasbenih tečajev je ustanovil glasłeno šolo v Portorožu (1948), iz katere se je razvil Center za glasbeno vzgojo v Kopru (prim. M. Studen, Kumar, Srečko, v: ES).

17 Grlica ie imela tekoče oštevilčene strani, in sicer skladbe z arabskimi, članke pa z rimskimi številkami.

sn Prim. E. Skulj, Kazalo slovenskib glasbenib revij, v: NZ 44 (1992), št. 6, 122-123.
} 
cla je vojna vihra uničila v Sloveniji skoraj vse izvode stare Grlice in cla je poleg tega dorasel mlajši rod zborovodij, ki stoje skoraj praznih rok ob svojih zborih. ${ }^{22}$ Po tej navezi na predvojno Grlico uredniški odbor ugotavlja naslednja dejstva: "Nov čas je utrdil novo miselnost, ki terja od nas novih, sodobnih in naprednih proizvodov umetnosti. Na drugi strani pa so se sprostile vse ukaželjne in glasbene kulture žejne sile ljudstva in našle izraza osnovanju neštetih novih glasbenih šol in zborov, ki so nas našli nepripravljene tako v pogledu strokovnega kadra. pedagoške doraslosti, zadostne kvantitete in kvalitete muzikalij itd."

Z 9. letnikom se je Grlica iz Revije za mladinsko zborovsko glasbo prelevila v Revijo zal glasbeno vzgojo, hkrati je odgovorno uredništvo prevzel Pavle Kalan. Sprememba je bila npovedana v uvodniku Grlica pred novimi nalogami, ki sta ga podpisala uredništvo in uprava. Sprememba ni bila toliko $v$ glasbenih prilogah kot $v$ knjižnem delu. Mdr. piše: "Razen člankov o vprašanjih glasbene vzgoje in primerov glasbenih učnih ur bomo letos objavili tudi druge zanimive in za slehernega glasbenega pedagoga koristne članke..$^{30}$

Z 12. (1967/68) letnikom je prevzel uredništvo Jakob Jež in ga obdržal do konca izhajanja revije. Kot profesor na Glasbenem oddelku nekdanje Pedagoške akademije $v$ Ljubljani si je Jakob Jež do konca te ustanove prizadeval za izboljšanje položaja glasbene vzgoje. Mnogim glasbenim učiteljem je bila Grlica edini pripomoček, iz katerega so črpali nove ideje za svoje pedagoškoustvarjalno delo. Uredništvo Grlice je znalo tenkočutno prisluhniti vprašanjem glasbene vzgoje, s svojim delovanjem skrbelo za primerno gradivo ter hkrati skušalo zapolniti vrzeli, ki so nastajale kot posledica odnosa širše družbene skupnosti do tega področja.

Pod Ježevim uredništvom je Grlica objavila številne kakovostne članke. V rednih rubrikah knjižne priloge je Grlica vplivala na kakovost glasbenopedagoškega dela.

1) Rubrika $\mathrm{V}$ razredu je prinesla primere vzornih nastopov $\mathrm{v}$ razredu, vzorce dobro zasnovanih učnovzgojnih priprav na pouk, prispevke o skupinski improvizaciji, glasbenih pravljicah, predšolski glasbeni vzgoji, prispevke o metodičnih vprašanjih inštrumentalnega pouka $v$ glasbenih šolah.

2) V rubriki Kako je z glasbeno vzgojo drugod, so bili objavljeni pogovori s priznanimi tujimi glasbenimi strokovnjaki, prevodi prispevkov iz tujih glasbenih revij in poročila naših pedagogov z obiskov v tujini.

3) V rubriki Naš razgovor oz. Predstavljamo vam je Grlica odprla pogled smerem in oblikam glasbenega delovanja: vsem področjem glasbene vzgoje od vzgojnovarstvenih ustanov do visokih strokovnih glasbenih šol; tu so pogovori z uspešnimi glasbenimi pedagogi, glasbenimi ustvarjalci in poustvarjalci (dirigenti, zborovodje), glasbenimi založniki, informacije o glasbenih knjižnicah, elektronskem studiu $v$ Beogradu, Orffovem institutu v Salzburgu, o glasbenoorganizacijskem delu, glasbenih festivalih ipd.

4) V rubrikah Zapisi, Vtisi, Ocene oz. Vesti in prikazi so zbrana poročila o delovanju pevskih zborov, zborovodskih seminarjih, republiških revijah pevskih zborov v Zagorju, o Mladinskem pevskem festivalu v Celju, o Zagrebškem bienalu, o republiških revijah in tekmovanjih učencev in študentov glasbe itd.

5) V rubriki Izšlo je Grlica seznanjala bralce $z$ novimi izdajami knjig in priročnikov z glashenega področja, plošč in notnega gradiva.

Notni del Grlice vsebuje skladbe, namenjene šolskim zborom. Veliko število skladb je nastalo prav na pobudo Grlice in so jih prispevali slovenski skladatelji od najstarejše do najmlajše sklaclateljske generacije. Izstopajo zlasti tematsko zaokrožene številke, ki izpričujejo skrb za kakovostno in zanimivo glasbeno literaturo: zbirka 63 kánonov $(12,1968$, št. 3) s

2) Naš delouni wačnt, v: Grlica 1 (1953/59), 1; uvodnik je podpisal Ureciniški odbor, vendar je napisan v prvi osebi ednine (-imislim-).

30 Grica pred norimi nalogami, v: Grlica 9 (1963), 1. 
pretežno novimi deli 25 slovenskih avtorjev in zbirka skladb za mladinski zbor v tehniki ostinata (15, 1972/73, št. 3-4). Dragocena je tudi izdaja Kogojevih pesmi za mladino (16, 1973/74, št. 3-5) s tehtno uvodno razpravo Po stopinjab časa in $\mathrm{z}$ uredniškim poročilom Boruta Loparnika. Korenit premik $\mathrm{v}$ načinu skladanja za mladino kaže prva v Grlici objavljena novotarska kompozicija Vožnja Lojzeta Lebiča $(17,1974 / 75$, št. 1-2). Temu je kmalu sledila sklenjena številka sicer ne izrazito korenitih, pa vendar svežih, preprostih in netradicionalno naravnanih 38 skladbic s spremljavo glasbil z naslovom Pojem-plě̌em Jakoba Ježa (18, 1975/76, št. 1-2).

Grlica je leta 1988 po 35 letih od ustanovitve, vendar v 28. letniku.3i sklenila svoje izhajanje. Na koncu preglednega članka, iz katerega so vzeti zgornji podatki, se Darja Frelih sprašuje: "Grlica je izgubila svoje gnezdo. Bodo njeni mladiči še kdaj radostno poleteli v svet? ${ }^{32}$

Če je slovensko glasbeno založništvo v 156 letih zmoglo kar štiri Grlice, zakaj ne bi v bližnji prihodnosti zmoglo še pete? Ali šeste?

31 Grlica je izhajala 35 let, vendar ima zaradi preskokov le 28 letnikov: 1 (1953/54), 2 (1955/56), 3 (1957), 4 (1958), 5 (1959), 6 (1960), 7 (1961), 8 (1962), 9 (1963), 10 (1964/65), 11 (1966), 12 (1967/68), 13 (1969/70), 14 (1971/72), 15 (1972/73), 16 (1973/74), 17 (1974/75), 18 (1975/76), 19 (1976/77), 20 (1978), 21 (1979), 22 (1980), 23 (1981), 24 (1982), 25 (1983), 26 (1984/85), 27 (1985/86), 28 (1987/88). Nekaj časa je izhajala po koledarskem, nato po šolskem letu. Tako je nastal zamik sedmilh let

32 Prim. D. Frelih, Grtica do današnjuga dne, v: Grlica 28 (1987/88), 122-123. 